\title{
HUMAN RESOURCE MANAGEMENT MODEL TO CREATE SUPERIOR PERFORMANCE
}

\author{
Tjutju Yuniarsih \\ Mochammad Dudih Sugiharto \\ Universitas Pendidikan Indonesia \\ tjutju@upi.edu
}

First draft received: 30 April 2016

Final proof received: 26 August 2016

\begin{abstract}
This research is motivated by the empirical conditions related to poor performance of human resources in various institutions in Indonesia. This research focuses on the uneven gains of competitive human resources due to workers' characters which still prioritize routines and the fact that quality-oriented work culture has not been strongly established.. The solution offered is a model of human resource management that emphasizes the interaction between personal and situational factors that are directed at the creation of improved performance and productivity, as stated in behaviourist theory. Based on the above explanation, the aim of this second year research is to measure the effects of the two previously mentioned factors on performance. The research adopted quantitative approach with explanatory survey method. First year research was focused on an exploration with inductive approach to map the determining factors for variables that will build a model of human resource management in achieving superior performance. Second year research used explanatory survey, combining multiple regression analysis techniques to test the causal relation between variables, while the third year research will use Research and Development method to test the hyphothetical model. The subjects of this research were employees in educational institutions (Indonesia University of Education and Bandung State Polytechnic), banks (West Java-Banten Bank and Indonesian People's Bank), business institutions (Advent Hospital), and government institutions (Local Government Agencies in Bandung). The size of the samples was taken proportionally from each work unit by using proportionate random sampling. The number of units of analysis was 239 respondents determined by Solvin formula. The instruments of this research consisted of questionnaires, interview guide, and documentary study. The instruments were validated by expert judgment. The data were processed with the aid of SPSS version 21 and AMOS to find the causal relationship between variables, and regression analysis to identify variables forming superior performance. Based on the findings, it can be concluded that all personal aspects and situational aspects were proven to have significantly positive effects and contributions to create superior performance. The hypothetical model developed in this first and second year research will be tested in the next year's research.
\end{abstract}

Keywords: Superior performance, personal factors, situational factors, human resource management.

To cite this paper (in APA style):

Yuniarsih, T. \& Sugiharto, M. D. (2016). Human resource management model to create superior performance. International Journal of Education, 9(1), 74-81. doi: dx.doi.org/10.17509/ije.v9i1.3721

\section{INTRODUCTION}

Ideal human resources are highly required in an organization. Quality human resources will be crucial to the success or failure of an organization to realize its objectives, and they need to be handled professionally. This research is motivated by the empirical conditions related to poor performance of human resources in various institutions in Indonesia. The poor performance is characterized by low levels of human development index in Indonesia, low competitiveness of various products in the global competition, the slow growth of the national economy, as well as delays in the development of national education quality. The root of the problem lies in the characters of workers who still give priority to the routines, while the quality-oriented work culture has not been strongly established. The solution offered is a model of human resource management that emphasizes the interaction between personal and situational factors that are directed at improved performance and productivity. Behavioral theory states that individual behavior basically flows from the characteristics of the individuals in relation to the situation they are in.
A number of studies have been conducted to better understand individual performance, both emphasizing the personal and situational aspects. Murray and Hernstein in Boulter, Dalziel and Hill (2003, p.1) stressed intelligence as a predictor for individual superior performance. On the other hand, Marshall in Boultier and Hill (2003, p. 38) asserted that the main predictor of an individual's superior performance is not his or her intelligence in understanding the job descriptions and fulfilling his or her duties, but it is the hidden personal characteristics, thoughts, and feelings that give birth to the individual's actions. These personal characteristics are called competences by McClelland (1973). Departing from these problems, the research focuses on the factors that shape superior performance and the indicators that establish each of the factors or variables.

The problem under research is the uneven distribution of excellent performance among Indonesian human resources. Referring to the behavioral theory, the research raises two issues, namely: the personal and situational factors that affect the superior performance of human resources. 
The problems above are formulated into the following questions: (1) Do the variables of the personal factors have effects on superior performance? and (2) Do the variables of situational factors have effects on superior performance?

In general, the research aims to understand the performance of human resources in various organizations by describing the personal and situational factors and to formulate constructs of human resource performance based on the two factors. More specifically, the aims are broken down into the following: (1) To measure the influence of each variable in personal factors on the superior performance of human resources; (2) To measure the influence of each variable in situational factors on the superior performance of human resources; and (3) To design a hypothetical model of human resource management to develop superior performance. Theoretically, the findings of this research are expected to contribute to the birth of new ways in encouraging superior performance so that the Indonesian institutions/organizations will have high competitiveness. Practically, the findings of this research will be made input to implement human resource management and give some advantages to future researchers to conduct further research on the field of human resource management.

\section{Human Resource Management}

Human resource is a strategic factor in both profit and non-profit organizations. According to Yuniarsih \& Suwatno (Yuniarsih \& Suwatno, 2011, p. 1), "Human Resource Management is a part of Management Sciences that focus on setting the roles of HR in the organization, with regard to both the implementation of managerial functions and operative functions." Covey $(2004$, p. 21) formulated the $4 \mathrm{~L}$ of human needs, namely "to learn, to live, to love, and to leave a legacy" combined with four complementary human components, which are "body, mind, heart, and spirit" (p. 313). The combination implies that human beings should be treated humanely as a holistic and perfect being.

The essence of human resource management study lies in its efforts to acquire human resources able to demonstrate superior performance with high productivity levels. Each individual is likely to contribute to the growth and development of the organization. Therefore, the study of human resource management is often associated with the study of organizational behavior. This research mainly focuses on the determining variables for an individual performance, both from the personal and situational factors. The personal factors include the variables of motivation, discipline, employee engagement, job satisfaction, organizational commitment, and competence; meanwhile, the situational factors include the variables of leadership, job characteristics, communication patterns, reward system, work-life balance, and organizational culture.

The implementation of human resource management concept is directed at individual behavior that can be in harmony with the demands of the situation (environment) to display superior performance. According to Mangkunegara (2005, p. 9 ), "HR performance is the achievements or output gained by an individual in a certain period of time in carrying out his or her duties in accordance with the responsibilities given to him". The superior performance of human resource is indicated by the optimal achievement of the targets of certain individual and organizational jobs. Hence, a transparent, objective, authentic, and accountable performance assessment is necessary. Referring to Moeheriono's opinion (2010, p. 106), assessment of individual performance can be based on four aspects, namely: Work, behaviors, attributes and competencies, as well as comparatives. On the other hand, Armstrong and Baron (in Wibowo, 2012, p. 246) argued that individual performance is measured based on the criteria of accountability in terms of quantity, quality, productivity, timeliness and costeffectiveness. In this study, superior performance is assessed based on the following indicators: cooperation and collaboration, the ability to communicate and interact, work quality, knowledge of the work, responsibility, productivity, adaptability and flexibility, as well as initiative and problem solving.

Work motivation is encouragement that can move a person to perform the desired activity in order to achieve the targeted results. Motivation can be divided into intrinsic motivation and extrinsic motivation. The instrument used to measure the level of employee motivation in the Final Report of Survey of Team Job Satisfaction at Bandung State Polytechnic (2011, p. 6), which is a part of this research, was developed from the view of Herzberg, namely: achievement, recognition, the work itself (job characteristics), responsibility (liability), and advancement (willingness and awareness of achievement to make progress in work).

Meanwhile, the term discipline is concerned with compliance with the various provisions governing the pattern of life in a particular social environment. Discipline can be enforced through reward and punishment. Reward and punishment in the discipline must be oriented to give lessons and develop people, thus raising the awareness of self-discipline on a permanent basis, not because of fear or want to get praised. Referring to Rivai and Sagala's statement (2009, p. 829), level of employee discipline can be measured according to five main components, which are attendance at work, adherence to labor regulations, adherence to labor standards, vigilance, and work ethics.

Next, employee engagement is a form of emotional engagement, satisfaction, and enthusiasm of individuals for the work performed. Engagement shows the level of involvement and a sense of employees' care to the work as well as their efforts to gain maximum results, both for themselves and the company (Robbins, 2009, p. 103). An employee with a strong desire to contribute optimally to the success of the organization will be the driving factor for engagement. They will work beyond standards and have high morale, motivation, loyalty, dedication, enthusiasm, pride and a strong sense of belonging. The high level of engagement demonstrated strong commitment to the organization.

Katz and Kahn (1996, p. 694) explained that employee engagement is "the harnessing of organization members' selves to their work roles; in engagement, people employ and express themselves physically, cognitively, and emotionally during role performances". The cognitive aspect of employee engagement involves an employee's belief about the organization, leaders, and working condition. The 
physical aspects cover individual's physical energy to perform his or her roles, while the emotional aspects involve concern for the organization and its leaders. According to Branham \& Hirschfeld (2010, p. 55), there are six universal driving forces for engagement, namely: "(1) Caring, Competent and Engaging Senior Leaders; (2) Effective Managers Who Keep Employees Aligned and Engaged; (3) Effective Teamwork at All Levels; (4) Job Enrichment and Professional Growth; (5) Valuing Employee Contributions; and (6) Concern for Employee WellBeing."

Based on the views of Katz and Kahn (1996, p. 694), Lamidi (2010, p. 194), and Shuck and Karen (2010, p. 160), it can be inferred that there are six primary dimensions in measuring employee engagement, which are vigor, dedication, absorption, cognitive (knowledge and interpretation of job), emotional, behavioral (natural reactions to the positive cognitive evaluation and the desires to invest personal potentials). sections.

Other components are described in the nex sub-

\section{Job Satisfaction}

According to Davis (2008, p. 96), "Job satisfaction is the favorableness or unfavorableness with which employees view/review their work; it expresses the amount of agreement between one's expectation of the job and the reward that the job provides." Job satisfaction is a reflection of employees' psychology as a result of his/her work. The level of individual satisfaction is basically guided by a value system held by the employee. Therefore, the basis for evaluation is in individual satisfaction (Rivai and Sagala, 2009, p. 856). Employees who are satisfied will have a positive attitude towards the organization, and be loyal, dedicated, and motivated to further improve productivity.

\section{Organizational commitment}

Organizational commitment demonstrates the confidence level of recruitment to the goals and values that develop within the organization. Robbins \& Judge (2009, p. 258) interpreted organizational commitment as the alignments of the individual against the organization, a strong desire to maintain their membership, a strong like for the organization, and willingness to promote the organization through various efforts. Referring to the ideas of Mathieu et al. (2008, pp. 68-83), there are three major dimensions that describe organizational commitment, namely: affective commitment, continuance commitment (an ongoing commitment), and normative commitment (normative commitment to the task and its consequences).

\section{Leadership}

Coveted leader is someone that can lead through a process of human interaction. Robbins \& Judge (2009) defined leadership as the ability to influence a group toward the achievement of a vision or the set goals. This indicates that leadership is a central factor in determining the policy of the organization. The essence of leadership is the quality of interaction that is based on credibility. "Credibility is about how leaders earn the trust and confidence of their constituents" (Kouzes and Posner, 2011: xi, 16). Credible leader is regarded as someone who is reliable, have a strong consideration when making decisions, behave and argue well, protect confidential information, and have the commitment to be a strong leader. Credibility is built by a leader's personal characteristics, such as visionary, honest, inspiring, competent, and able to behave consistently.

\section{Job Characteristics}

Another factor that determines performance is characteristics of the work itself. A model of job characteristics by Hackman and Oldham (2007, p. 217), an approach to the enrichment of the post (job enrichment), is broken down into five dimensions of the core characteristics, which are diversity of skills (skill variety), task identity, task significance, autonomy, and feedback. Job characteristics are seen in the design work. Basically, redesigning work is how to rearrange the structure of employment in order to have a higher internal trust to the performance and productivity of employees, so that the work can be completed better and faster.

\section{Communication Pattern}

The term communication can be defined as a process of delivering messages (information) to other parties with a specific purpose. The effectiveness of communication is marked by the creation of a common understanding (mutual understanding) between the parties who communicate. More specifically, Rohim (2009, pp. 113-114) explained that organizational communication has four important functions, those are: (1) informative function, (2) regulatory function, (3) persuasive function, and (4) integrative function. Referring to the opinion of Pace and Faules in Mulyana (2011, p. 497), communication consists of the elements: satisfaction of the organization, organizational climate, quality of the information media, accessibility of information, dissemination of information, load of information, accuracy of the message, and culture of the organization.

\section{Reward System}

Reward includes all expenditures of an institution received or enjoyed by employees, either directly or indirectly, routinely or incidentally (Ruky, 2007, p. 109). Simamora (2003, p. 89) used the term of compensation or remuneration, which is interpreted as the financial rewards earned through employment relationship with the organization. McKenna and Beech (2007, p. 245) confirmed that the provision of rewards and incentives can also form a non-financial (psychological) relationship.

Based on the need to motivate the employee, reward system approach is the right choice to establish the performance of individuals and organizations. Motivation and rewards are interrelated in achieving the level of job satisfaction (McKenna \& Beech, 2007, p. 259). In this regard, compensation categorized as extrinsic rewards that include salary/wages, various types of allowances, insurance premiums, and the like, while the intrinsic components of awards come from self-esteem, satisfaction with work performance, increased psychological health, intellectual growth and emotional maturity, increased social welfare, increased coworker relationships, as well as support for the provision of employment opportunities to the management (Mc Kenna \& Beech, 2007, p. 264). 


\section{Previous Research}

The research by Sugiharto (2014), Rohayati (2013), Kari (2013), in general show that the variable of leadership has a positive relationship with organizational commitment of employees (Farid, 2004) and has significant influence on job satisfaction (Morisson, 2003). Another body of research found that job characteristics have a positive relationship to organizational commitment, (Eby et al., 2005; Colbertlk \& Kwon, 2006). In a meta-analysis study of organizational commitment, it was found that the scope of work, challenges, and a high degree of autonomy (independence) have a strong relationship with employees' organizational commitment (Mathieu \& Zajac, 1999; Laschinger, Finegan \& Shamian, 2009). A more detailed analysis was carried out by Colbertlk \& Kwon (2006), which explained that the dimensions of task identity, task significance, autonomy, and feedback all have a positive relationship with organizational commitment. Of the two meta-analysis studies, Mathieu and Zajac (1999) and Cohen \& Hudecek (2003) demonstrated that organizational commitment has a very strong relationship with the antecedents variables, such as age, marital status, employment status (occupational status), working life, and also a similarly strong relationship with the variables of working conditions (Brewer, 1998), job satisfaction, labor turnover (Cohen \& Hudecek, 2003), work performance, organizational climate (McElroy, Morrow, Crum \& Dooley, 1998 ) and stress (Savery \& Syme, 1996).

The research findings mentioned above become the basis for determining the scope of the issues examined. The scope of the study included personal and situational aspects that can affect the superior performance of human resources. Based on the report of the first year research (Yuniarsih, Disman, \& Suryadi, 2014, pp. 97-98), it is found that:

1. There are eight indicators forming employee performance, namely: cooperation and collaboration, the ability to communicate and interact, work quality, knowledge of the work, responsibility, productivity, adaptability and flexibility, initiative and problem solving.

2. There are five indicators forming work motivation, namely: recognition, development (advancement), responsibility, achievement, and the work itself.

3. There are five indicators forming work discipline, namely: adherence to the rules, attendance, adherence to labor standards, work ethic, and the level of vigilance.

4. There are six indicators forming the variable of employee engagement, namely: vigor, cognition, behavior, dedication, appreciation (absorption), and emotion.

5. There are six indicators forming job satisfaction variable, namely: supervision, work environment, promotion, coworker support, work that is mentally challenging, and the reward in the form of wages/salary.

6. There are three indicators forming organizational commitment, namely: attachment (normative commitment), emotional attachment (affective commitment), and life continuance (continuance commitment).

7. There are two indicators forming leadership variable, namely: relationship-oriented behavior, and task-oriented behavior.

8. There are six indicators forming the variable of job characteristics, namely: identification of tasks, autonomy, significance tasks, skills variety, feedback from others, and feedback from work.

9. There are five indicators forming the variable of communication patterns, namely: messaging accuracy, dissemination of information, load of information, information media quality, and accessibility of information.

10. There are five indicators forming the variable of award system, namely: method of award, distributive justice, procedural fairness, intrinsic award (reward), and extrinsic awards (reward).

In the second year of the study, the effect of each independent variable, both personal and environmental aspects, on the performance, and the influence of the independent variables on performance through job satisfaction and organizational commitment were tested. For this purpose, the hypotheses of the present study can be stated as follows: (1) There are positive effects of the factors included in the personal aspects (motivation, discipline, employee engagement, satisfaction, and commitment) on superior performance, and (2) There are positive effects of the factors included in the environmental aspects of the organization (leadership, job characteristics, award systems, and communication patterns) on superior performance.

\section{METHOD}

The second year research adopted a quantitative approach with explanatory survey method, combined with the technique of multiple regression analysis to examine the causal relationships between the variables and test hypotheses (Sugiama, 2008, p. 38; Rusidi, 1992, p. 24; Cooper and Emory, 1995, p. 111; Singarimbun \& Effendi, 1995, p. 131). Based on the goal, the research is a descriptive verification, aimed to get an overview of the indicator variables and measure relationships. The subjects were individual members of the population as respondents defined into the unit of analysis, while the research objects were those related to the variables analyzed. The unit of analysis covered various organizations, namely: educational institutions, banks, business organizations, and government agencies.

The population included individual employees $(\mathrm{HR})$ at the locations under research. The size of the samples was determined proportionally in each unit of work, to make it more representative. The sample selection technique used proportionate random sampling, while the sample and analysis units involved 293 respondents, calculated based on Slovin formula. The main instrument of this study was a questionnaire with Likert Scale, supported by interviews and documentation, whereas the literature review technique was used to obtain the basic theory. The instrument was validated by the judgment of experts through a focus group discussion (FGD).

The model used in this study was causality model. Data were processed using SPSS version 17 aided by some applications and AMOS and multiple regression analysis to identify variables forming superior performance. After the quantitative data were analyzed according to the provisions and 
procedures of statistical analysis model, the data were then interpreted based on the FGD and justification of the research team, to be arranged into the final report of the study and written into a research article.

\section{FINDINGS AND DISCUSSION}

\section{Variables influencing excellent performance}

Based on calculations using SPSS version 21.00, the influences of the variables of Leadership (KEP), job characteristics (KP), Award System (SP), Discipline (DIS), Motivation (MOT), Communication Patterns (PK), Employee Engagement (ENG), job satisfaction $(\mathrm{KK})$, and Organizational commitment (KOM) on Superior Performance (KIN) are illustrated in the following chart.

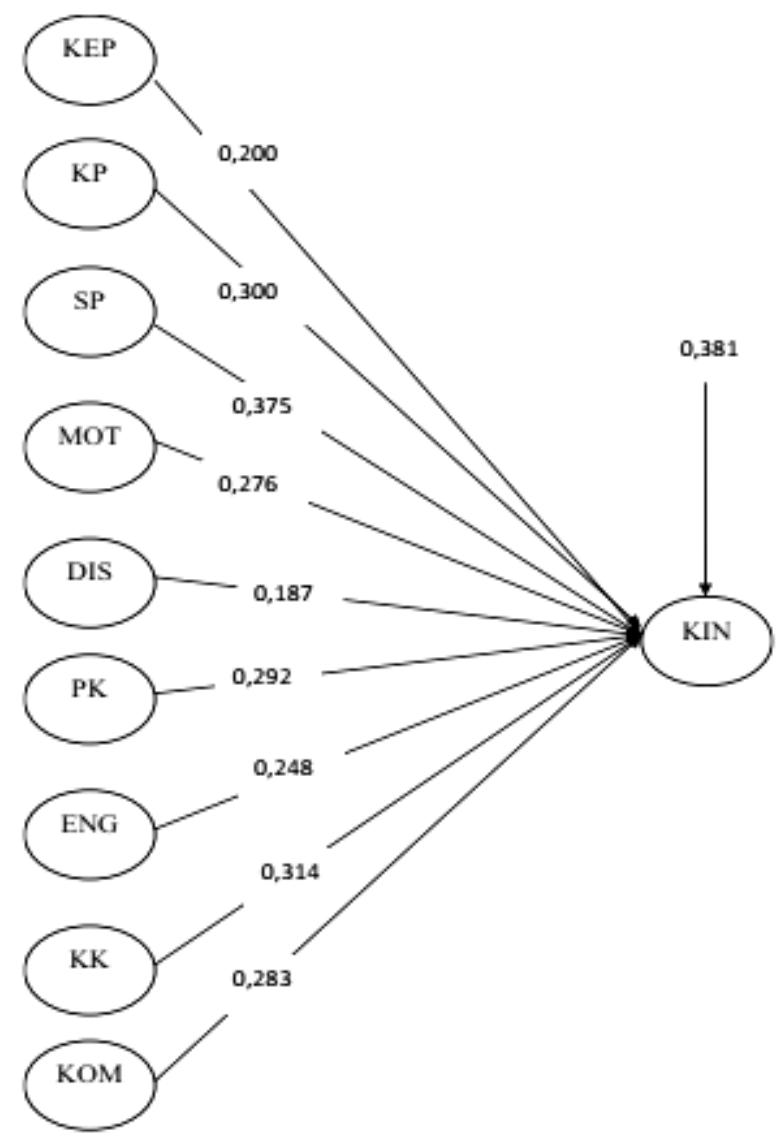

Figure 1. The Effects of the Independent Variables on Superior Performance

Based on Figure 1 above, it is clear that all of the independent variables had significantly positive effects on superior performance. This is proven by the value of coefficient of determination of 0.381 , meaning that performance change can be explained by leadership, job characteristics, reward systems, motivation, discipline, communication patterns, employee engagement, job satisfaction, and organizational commitment for 0.619 or $61.90 \%$, and the remaining $38.1 \%$ is explainable by other variables not included in the model.

This research developed a model of factors affecting superior performance in banks, educational institutions, businesses, and government institutions. Figure 1 indicates that the levels of variables' effects on performance can be listed in the following order: Reward System (SP) for 0.375, Job Satisfaction (KK) 0.314, Job Characteristics (KP) 0.300, Communication Patterns (PK) 0.292, Organizational Commitment (KOM) 0.283, Motivation (MOT) 0.276, Employee Engagement (ENG) 0.248, Leadership (KEP) 0.200, and Discipline (DIS) 0.187

Reward system is the variable with the most significant effect on performance. Employees perceive that reward method is fair and in line with their needs, thereby encouraging them to achieve and compete healthily. The significant effect of the variable of job satisfaction is supported by a leader's supervision that is persuasive, so that a harmonious internal relationship is developed as an attempt of cultivating a sense of togetherness between employees and leaders.

The variable of discipline had the least significant effect on performance. Similar result was obtained for the variable of motivation, showing that employees are more concerned with the obligations to abide by the rules, especially in fulfilling their duties. Hence, their need to always be under leaders' supervision is really high.

Based on the results of the statistical test, the exogenous variables consisting of leadership, job characteristics, reward system, discipline, motivation, communication patterns, employee engagement, job satisfaction, and organizational commitment had direct significant effects on superior performance. This finding means that the personal and situational factors contribute to the achievement of employees' superior performance. 
The Hypothetical Model of Human Resource Management

Based on the analysis and findings previously explained, the hypothetical model of Human
Resource Management for Superior Performance with behavioral approach can be formulated as illustrated in the following figure.

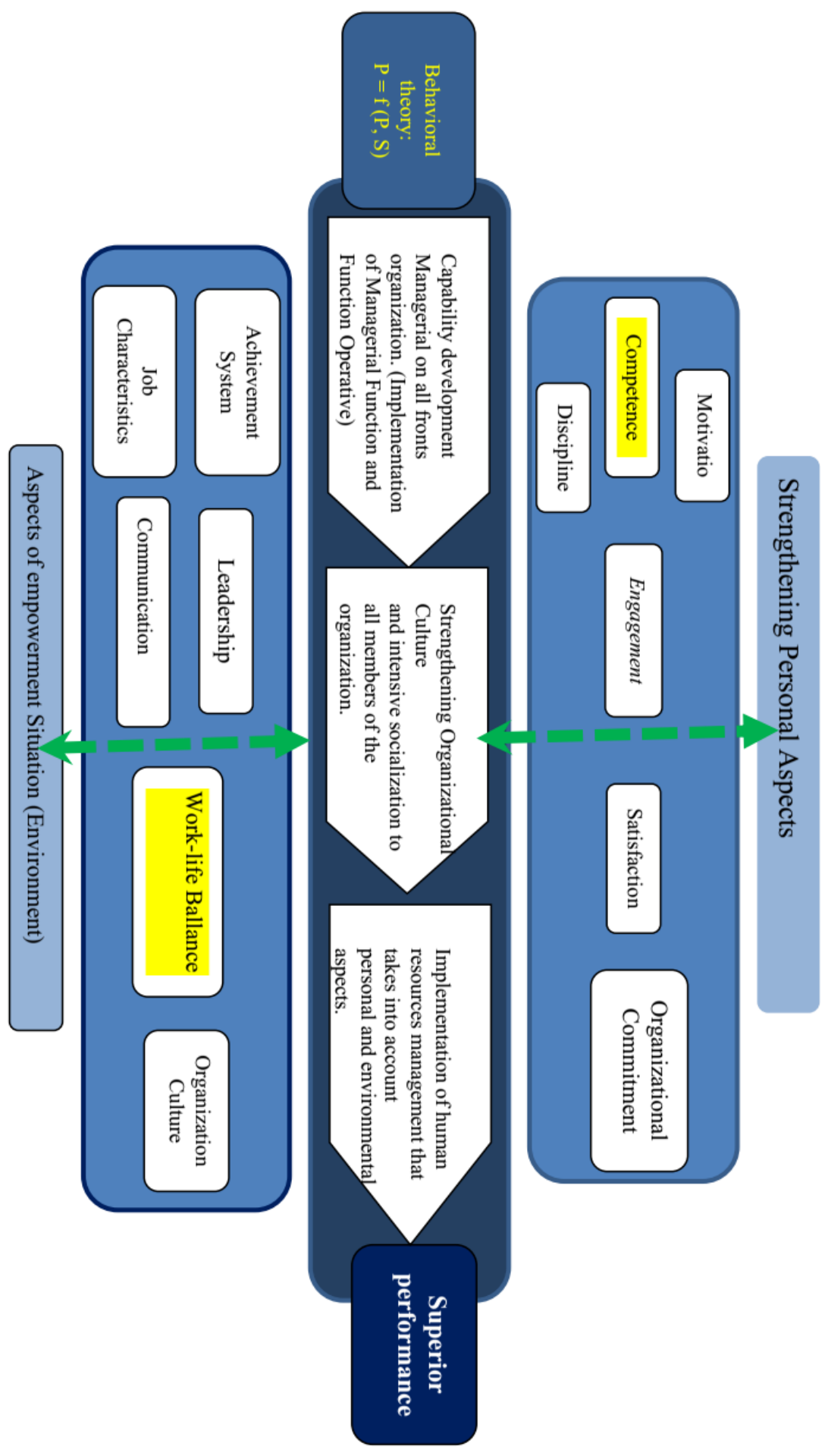

Figure 2. The hypothetical model of human resource management for superior performance

\section{CONCLUSION}

In the personal factors, the variables that significantly contribute to superior performance are motivation, discipline, employee engagement, job satisfaction, and organizational commitment; meanwhile, in terms of situational factors, the variable that contribute significantly to superior performance are leadership, job characteristics, reward system, and communication pattern. There were significantly positive effects of personal and situations factors on the development of superior performance. Based on the above findings, the following recommendations 
are made: (1) An organization's superior performance is the result of cooperation of the whole organization members; thus, a solid teamwork supported by situational leadership style that combines concern for tasks and human relations is needed, (2) Employees' low discipline should be solved with strategic steps by making binding rules and relate them to reward system, and (3) The design of Human Resource Management Model to Create Superior Performance with behavioral approach can be considered as an alternative model.

\section{REFERENCES}

Boulter, N., Dalziel, M., \& Hill, J. (2003). People and competencies: The route to competitive advantage (The Art of HRD). Jakarta: Bhuana Ilmu Populer.

Branham, L. \& Hirschfeld, M. (2010). Re-engage. How America's best places to work. Inspire extra effort in extraordinary times. USA MacGraw-Hill.

Brewer, A.M. (1998). Developing commitment between managers and employees. Journal of Managerial Psychology, 3, 34-44.

Cohen, A. \& Hudecek, N. (2003). Organizational commitment-turn over relationships across occupational groups: A meta analysis. Group And Organization Management, 26, 201-243.

Colbertlk, A.E. \& Kwon, W.G. (2006). Factors related to the organizational commitment of college and university auditors. Journal of Management Issues. 14, 478-497.

Cooper, D. \& Emory, C.W. (1995). Business research methods (Fifth Edition). Homewood, IL: Richard D. Irwin Inc.

Covey, S.R. (2004). The $8^{\text {th }}$ habit: From effectiveness to greatness. New York: Free Press.

Davis, K. (2008). Human behavior at work: Organizational behavior. Boston, Mass: Grolier Inc.

Eby, L.T., Freeman, D.M., Rush, M. \& Lance, C.E. (2005). Motivational bases of affective organizational commitment: A partial test of an integrative theoretical model. Journal of Occupational and Organizational Psychology, 75, 384-405.

Farid, H. I, (2004). Job characteristics, leaderships, and organizational commitment as perceived by managers in the Egyptian public and private sectors. Academy of Strategic and Organizational Leadership Journal, 3, 262-294.

Hackman, JR. \& Oldham, G.R. (2007). Work redesign. Sixth Edition. New York: Addison.

I-Mhere, (2011). Survey kepuasan dan motivasi kerja (A survey of job satisfaction and motivation). Politeknik Negeri Bandung.

Kari, K. (2013). Pengaruh kepuasan dan motivasi kerja pegawai terhadap engagement pegawai tenaga kependidikan di Politeknik Negeri Bandung (The effects of job satisfaction and motivation on employee engagement among education personnel at Bandung State Polytechnic) [Unpublished Master's Thesis]. Bandung: The School of Post-Graduate Studies of Universitas Pendidikan Indonesia.

Katz, D. \& Kahn, R. (1996). The social psychology of organizations. New York: John Wiley.
Kouzes, J. \& Posner, B.Z. (2011). Credibility. How leaders gain and lose it. Why people demand it. San Fransisco: Jossey-Bass.

Lamidi (2010). Efek modernisasi kepemimpinan pada pengaruh employee engagement terhadap kepuasan kerja (The effects of leadership modernization on employee engagement and job satisfaction). Jurnal Ekonomi dan Kewirausahaan, 10(2), 190-200.

Laschinger, H.K.S, Finegan, J. \& Shamian, J. (2009). The impact of workplace empowerment, organizational trust on staff nurses, work satisfaction and organizational commitment. Health Care Management Review, 28, 9-28.

Mangkunegara, A.P. (2005). Manajemen sumber daya manusia perusahaan (Management of company's human resources). Bandung: Remaja Rosdakarya.

Mathieu, A., Bruvold, N.T. \& Ritchey, P.N. (2008). Subcultural research on organizational commitment with the $15 \mathrm{OCQ}$ invariant instrument. The Journal of Personal Selling \& Sales Management, 26, 228-242.

Mathieu, A. \& Zajac, D.M. (1999). A review and meta analysis of the antecedent, correlates, and consequences of organizational commitment. Psychological Bulletin, 112, 182-206.

McClelland, D. (1973). Testing for competence rather than for "intelligence." American Psychologist, 1, 1-14.

McElroy, J.C., Morrow, P.C., Crum, M.R. \& Dooley, F.J. (1998). Railroad employee commitment and work related attitudes and perceptions. Transportation Journal, 36, 18-30.

McKenna, E. \& Beech, N. (2007). The essence of human resource management. London: Prentice Hall International, Ltd.

Moeheriono. (2010). Pengukuran kinerja berbasis kompetensi (Performance assessment based on competences). Bogor: Ghalia Indonesia.

Morrison, K.A. (2003). How franchise job satisfaction and personality affect performance, organizational commitment, franchise relation and intention to remain. Journal of Small Business Management, 38, 49-77.

Mulyana, D. (2011). Ilmu komunikasi: Suatu pengantar (Communications: An introduction). Bandung: Remadja Rosdakarya.

Oktafien, S. (2014). Pengaruh kualitas kehidupan kerja, komunikasi dalam organisasi, kepuasan kerja, dan disiplin kerja terhadap kinerja pegawai. (Studi pada PNSD di lingkungan Pemerintah Kota Bandung) (The effects of work life quality, organization's internal communication, job satisfaction, and discipline on employee performance: A study of regional civil servants in the Municipal Government of Bandung) [Unpublished Master's Thesis]. Bandung: The School of Post-Graduate Studies of Universitas Pendidikan Indonesia.

Rivai, V. \& Sagala, E.J. (2009). Manajemen sumber daya manusia untuk perusahaan. Dari teori ke praktik. Jakarta: Rajagrafindo Persada.

Robbins, S.P., \& Judge, T.A., (2009). Organizational behavior, $12^{\text {Th }}$ Edition. New Jersey: Pearson Education, Inc, Upper Saddle River.

Rohayati. (2013). Pengaruh kepemimpinan kredibel terhadap engagement dan implikasinya 
terhadap kinerja pegawai Universitas Pendidikan Indonesia (The effects of credible leadership on engagement and their implications for the performance of employees at Universitas Pendidikan Indonesia) [Unpublished Master's Thesis]. Bandung: The School of Post-Graduate Studies of Universitas Pendidikan Indonesia.

Rohim, S. (2009). Teori komunikasi: Perspektif, ragam \& aplikasi (Communication theory: Perspectives, types, and application). Jakarta: Rineka Cipta.

Ruky, A.S. (2007), Manajemen penggajian \& pengupahan untuk karyawan perusahaan (Management of salary and wage for company's employees). Jakarta: Gramedia Pustaka Utama.

Rusidi. (1992). Dasar-dasar penelitian dalam pengembangan ilmu (Basics of research in science development). Bandung: Post-Graduate Program of Universitas Padjadjaran.

Savery, K.L. \& Syme, D.P. (1996) Organisational Commitment and Hospital Pharmacists. Journal of Management Development, 15, 14-22. http://dx.doi.org/10.1108/02621719610107773

Shuck, B. \& Karen, W. (2010). Employee engagement and HRD: A seminal review of the foundations. SAGE, 89-110. Available at: http://hrd.sagepub.com/

Simamora, H. (2003). Manajemen sumber daya manusia (Human resource management). Yogyakarta: STIE YKPN
Singarimbun, M. \& Effendi, S. (1995). Metode penelitian survai (Survey research method). Jakarta: LP3ES.

Sugiama, A.G. (2008). Metode riset bisnis dan manajemen (Business and management research method). Bandung: Guardaya Intimarta.

Sugiharto, M.D. (2013). Pengaruh kepemimpinan, karakteristik pekerjaan, dan sistem penghargaan terhadap kepuasan kerja, serta implikasinya terhadap komitmen pegawai Bank BJB Syariah (The effects of leadership, job characteristics, and reward system on job satisfaction, and their implications for employee commitment at Bank BJB Syariah) [Unpublished Dissertation]. The School of Post-Graduate Studies of Universitas Pendidikan Indonesia.

Wibowo. (2012). Manajemen kinerja (Performance management). Jakarta: Rajawali Pers.

Yuniarsih, T., \& Suwatno. (2011). Manajemen sumber daya manusia. Teori, aplikasi, dan isu penelitian (Human resource management: Theory, application, and issues in research) Third edition. Bandung: Alfabeta.

Yuniarsih, T., Disman, \& Suryadi, E. (2014). Model manajemen sumber daya manusia untuk membentuk kinerja unggul (A Model of human resource management to form superior performance). First Year Research Report. Unpublished. Bandung: LPPM UPI. 